\title{
Correction to: Effect of Particle and Carbide Grain Sizes on a HVOAF WC-Co-Cr Coating for the Future Application on Internal Surfaces: Microstructure and Wear
}

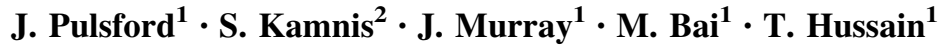

Published online: 29 May 2018

(C) The Author(s) 2018

\section{Correction to:}

$$
\begin{aligned}
& \text { J Therm Spray Tech (2018) 27:207-219 } \\
& \text { https://doi.org/10.1007/s11666-017-0669-8 }
\end{aligned}
$$

The article "Effect of Particle and Carbide Grain Sizes on a HVOAF WC-Co-Cr Coating for the Future Application on Internal Surfaces: Microstructure and Wear", written by Pulsford et al., was originally published electronically on the publisher's internet portal (currently SpringerLink) on 1st December 2017 without open access. With the author(s)' decision to opt for Open Choice the copyright of the article changed on June 5, 2018 to (c) The Author(s) 2017 and the article is forthwith distributed under the terms of the Creative Commons Attribution 4.0
International License (http://creativecommons.org/licen ses/by/4.0/), which permits use, duplication, adaptation, distribution and reproduction in any medium or format, as long as you give appropriate credit to the original author(s) and the source, provide a link to the Creative Commons license and indicate if changes were made. The original article was corrected.

Open Access This article is distributed under the terms of the Creative Commons Attribution 4.0 International License (http://crea tivecommons.org/licenses/by/4.0/), which permits unrestricted use, distribution, and reproduction in any medium, provided you give appropriate credit to the original author(s) and the source, provide a link to the Creative Commons license, and indicate if changes were made.
The original article can be found online at https:// doi.org/10.1007/s11666-017-0669-8.

J. Pulsford

enxjcp@nottingham.ac.uk

T. Hussain

tanvir.hussain@nottingham.ac.uk

1 Faculty of Engineering, University of Nottingham, Nottingham NG7 2RD, UK

2 Castolin Eutectic-Monitor Coatings Ltd., North Shields NE29 8SE, UK 